\title{
EARLY-ONSET CENTRAL DIABETES INSIPIDUS IN A NEWBORN WITH HOLOPROSENCEPHALY
}

\author{
HOLOPROZENSEFALI TANILI BIR YENIDOĞANDA ERKEN BAŞLANGIÇLI SANTRAL \\ DIABETES INSIPIDUS
}

\author{
Mustafa Törehan ASLAN ${ }^{1}$ iD, Zeynep INCE ${ }^{1}$ (D), Asuman ÇOBAN ${ }^{1}$ (D) \\ ${ }^{1}$ Istanbul University Istanbul Faculty of Medicine, Department of Pediatrics, Division of Neonatology, Istanbul, Turkey
}

ORCID IDs of the authors: M.T.A. 0000-0002-3966-4635; Z.i. 0000-0002-7304-099X; A.Ç. 0000-0001-6573-242X

Cite this article as: Aslan MT, Ince Z, Coban A. Early-onset central diabetes insipidus in a newborn with holoprosencephaly. J Ist Faculty Med 2021;84(4):599-602. doi: 10.26650/IUITFD.2021.807168

\begin{abstract}
Holoprosencephaly is a complex brain malformation caused by the inability of the prosencephalon to divide to form the cerebral hemispheres. Central diabetes insipidus (CDI), as a result of a defect in vasopressin release, may be seen due to the abnormal hypothalamic infundibular region. CDI developing secondary to holoprosencephaly in the early neonatal period has rarely been reported in the literature. A case of early-onset CDI with holoprosencephaly and $13 \mathrm{q}$ deletion is presented.
\end{abstract}

Keywords: Holoprosencephaly, central diabetes insipidus, newborn, desmopressin

\section{ÖZET}

Holoprozensefali, prozensefalonun serebral hemisferleri oluşturmak için bölünmesi sırasındaki yetersizlikten kaynaklanan kompleks bir beyin malformasyonudur. Anormal hipotalamik infundibular bölge nedeniyle vazopressin salınımındaki kusura bağlı santral diabetes insipidus (SDI) görülebilmektedir. Erken neonatal dönemde holoprozensefaliye ikincil gelişen SDi vakası enderdir. Holoprozensefali ve $13 q$ delesyonu olan erken başlangıçlı bir SDi vakası sunulmuştur.

Anahtar Kelimeler: Holoprozensefali, santral diabetes insipidus, yenidoğan,

\section{INTRODUCTION}

Holoprosencephaly (HPE) is a complex brain malformation caused by the failure of the prosencephalon to divide between the $35^{\text {th }}$ and $42^{\text {nd }}$ days of embryonic life. Depending on the degree of septation deficiency, it can occur in three forms as alobar, semilobar and lobar. The incidence of alobar HPE has been reported to be 0.6-1.9 per 10,000 live births. Holoprosencephaly can either be isolated or accompany various syndromes. The prognosis depends on the severity of the brain and facial deformities along with the presence of related anomalies. Alobar HPE carries the worst prognosis among other prosencephalon division anomalies. Central diabetes insipidus (CDI) may be an accompanying feature due to a defect in vasopressin release as a result of abnormalities in the hypothalamic infundibular region $(1,2)$.

\section{CASE PRESENTATION}

A baby boy with a birth weight of 3,000 grams (AGA) was born to a 34-year-old $\mathrm{G}_{6} \mathrm{P}_{4} \mathrm{~A}_{2}$ mother at 39/7 weeks of gestation. Antenatal ultrasonography (USG) showed that the fetus had HPE and corpus callosum agenesis. After birth the baby was admitted to the neonatal intensive care unit for further investigation and follow-up. The history of the mother revealed two previous pregnancies, one resulting in miscarriage at the $8^{\text {th }}$ week and the other live birth with HPE who died at the age of 5.5 years. No genetic analysis had been performed for either the child who died with holoprosencephaly or the two miscarriages. The parents were first degree cousins. Microcephaly, slanted palpebral fissures, hypotelorism, clinodactyly in the fifth finger of the left hand and mild hypertonicity were detected on physical examination (Figure 1).

Corresponding author/Iletişim kurulacak yazar: torehanaslan@yahoo.com

Submitted/Başvuru: 07.10.2020 • Revision Requested/Revizyon Talebi: 17.12.2020 •

Last Revision Received/Son Revizyon: 23.12.2020 • Accepted/Kabul: 28.12.2020 • Published Online/Online Yayın: 17.09.2021 


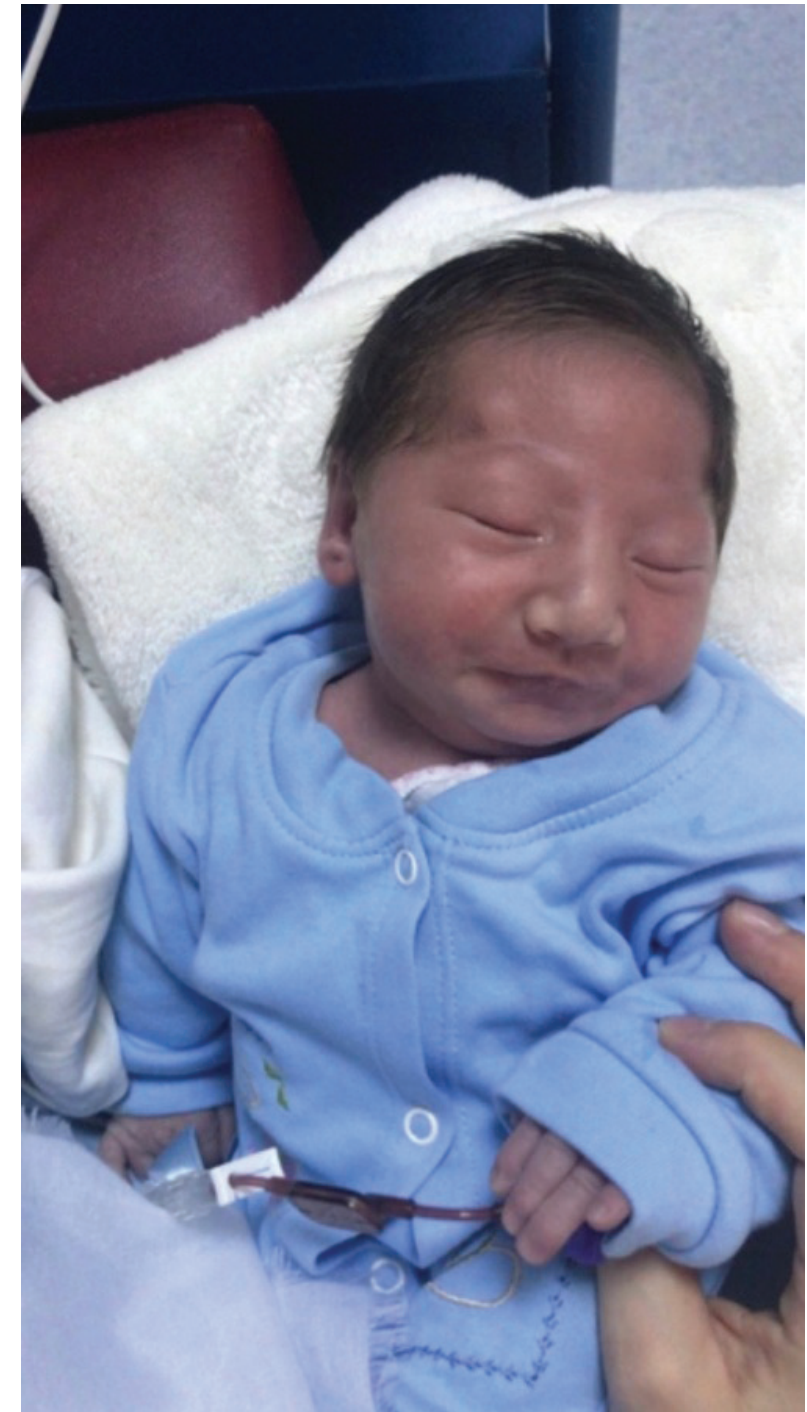

Figure 1: External appearance of the patient

Cranial magnetic resonance imaging showed semilobar HPE with fusion in the thalami, agenesis of corpus callosum and interhemispheric fissure, fusion of lateral ventricles at the corpuscular level and dilatation in the fourth ventricle and cisterns (Figure 2).

In the first three days of life, the baby fed well and there was no pathological weight loss. However, on the $4^{\text {th }}$ postnatal day, polyuria developed (urine output: $5.9 \mathrm{cc} /$ $\mathrm{kg} / \mathrm{hour})$. Daily weight loss was high (5.4\%/day). Serum biochemistry results were as follows: urea $40.8 \mathrm{mg} / \mathrm{dL}$, creatinine $1.05 \mathrm{mg} / \mathrm{dL}$, BUN $19.7 \mathrm{mg} / \mathrm{dL}$, sodium 149 $\mathrm{mEq} / \mathrm{L}$ and other electrolytes were normal. Blood gases revealed pH 7.31, pCO2 $42 \mathrm{mmHg}, \mathrm{HCO} 320.4 \mathrm{mEq} / \mathrm{L}$, base deficit $-2.1 \mathrm{mEq} / \mathrm{L}$, lactate $1.3 \mathrm{mEq} / \mathrm{L}$, and glucose $87 \mathrm{mg} / \mathrm{dL}$. Sepsis markers were negative. Urinary sodium level was $14 \mathrm{mEq} L$, urine density was 1,002 while serum osmolarity was $325 \mathrm{mOsm} / \mathrm{L}$. Blood cortisol level

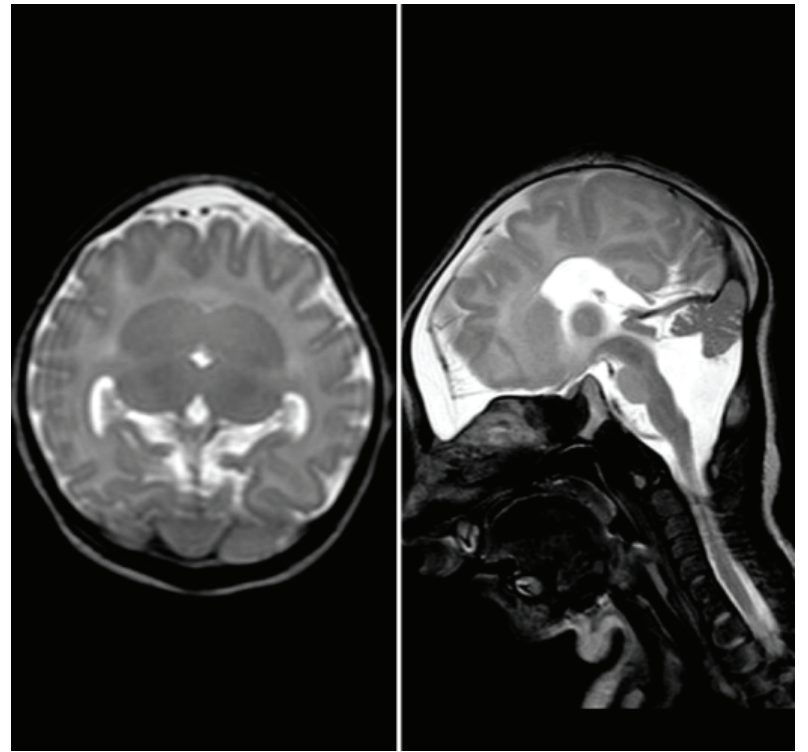

Figure 2: Cranial magnetic resonance imaging sections (holoprosencephaly and corpus callosum agenesis)

$(6.26 \mathrm{mcg} / \mathrm{dL})$, renin activity $(4.02 \mathrm{ng} / \mathrm{mL} /$ hour $)$, aldosterone level $(80.7 \mathrm{ng} / \mathrm{dL}$ ) and thyroid function tests (thyroid stimulating hormon (TSH) $5.21 \mathrm{pmol} / \mathrm{L}$, free thyroxine (T4) $25.1 \mathrm{mIU} / \mathrm{L}$ ) were normal. Although enteral feeding and parenteral fluid support was gradually increased to a total of $250 \mathrm{cc} / \mathrm{kg} /$ day, polyuria continued and serum sodium levels increased $(156 \mathrm{mEq} / \mathrm{L})$ on the postnatal $5^{\text {th }}$ day. Oral desmopressin $1.2 \mu \mathrm{g} /$ day was started and the dose was increased to $2.4 \mu \mathrm{g} /$ day according to the clinical findings and laboratory results of the patient. On the $3^{\text {rd }}$ day of the treatment, blood sodium levels and urine output returned to normal values (Table 1). Parenteral fluid support was gradually decreased while oral intake was increased. On the postnatal $9^{\text {th }}$ day, parenteral fluids were discontinued completely. The genetic test results showed a deletion in the long arm on the chromosome 13. On the postnatal $11^{\text {th }}$ day, the baby started to gain weight and his laboratory values and urine output were normal. The patient, who did not need parenteral fluid support and was fed with breast milk, was discharged with oral desmopressin treatment $(2.4 \mu \mathrm{g} /$ day $)$

\section{DISCUSSION}

Holoprosencephaly (HPE) is the most common malformation of the prosencephalon, which cannot be separated into two hemispheres and ventricles. It is a midline growth and separation defect characterized by severe malformations of the face and brain, often resulting in intrauterine death. Approximately $25-50 \%$ of individuals with HPE have a chromosomal abnormality. Chromosomal abnormalities are nonspecific and either numeric or structural, and can involve any chromosome (3). The region on chromosome $13 q$ contains the ZIC2 
Table 1: Follow-up during hospitalization

\begin{tabular}{|c|c|c|c|c|c|c|c|c|c|c|c|}
\hline Days of life & 1 & 2 & 3 & 4 & 5 & 6 & 7 & 8 & 9 & 10 & 11 \\
\hline $\begin{array}{l}\text { Total fluid } \\
\text { (mL/kg/day) }\end{array}$ & 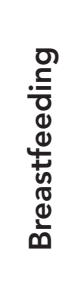 & 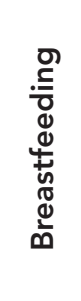 & 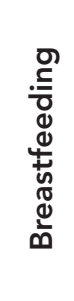 & 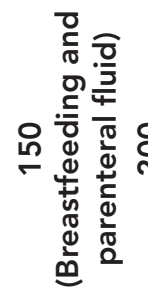 & 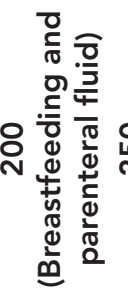 & 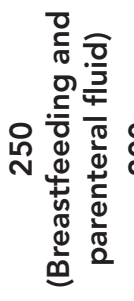 & 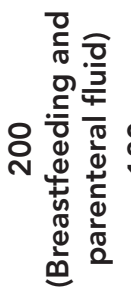 & 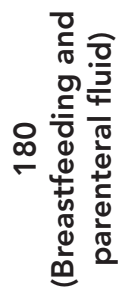 & 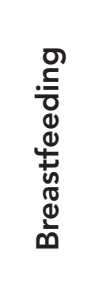 & 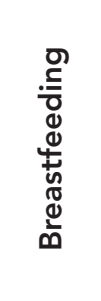 & 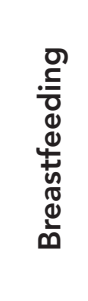 \\
\hline $\begin{array}{l}\text { Daily weight } \\
\text { difference (\%) }\end{array}$ & -1.2 & -2.5 & -3.1 & -5.4 & -2.1 & -1.5 & +3.6 & +3.4 & +2.9 & +1.4 & +0.9 \\
\hline $\begin{array}{l}\text { Serum sodium } \\
\text { (mEq/L) }\end{array}$ & - & - & 146 & 149 & 156 & 151 & 144 & 142 & 140 & 138 & 139 \\
\hline $\begin{array}{l}\text { Serum osmolarity } \\
\text { (mOsm/L) }\end{array}$ & - & - & - & 325 & 332 & 304 & 297 & 289 & 278 & 280 & - \\
\hline $\begin{array}{l}\text { Diuresis } \\
\text { (cc/kg/hour) }\end{array}$ & - & - & - & 5.9 & 5.4 & 4.1 & 2.3 & 2.0 & 2.5 & 2.1 & 2.2 \\
\hline $\begin{array}{l}\text { Urine osmolarity } \\
(\mathrm{mOsm} / \mathrm{L})\end{array}$ & - & - & - & 79 & 75 & 108 & 197 & 264 & 262 & 256 & - \\
\hline Urine density & - & - & - & 1002 & 1002 & 1003 & 1009 & 1011 & 1011 & 1010 & 1011 \\
\hline $\begin{array}{l}\text { Spot urine sodium } \\
(\mathrm{mEq} / \mathrm{L})\end{array}$ & - & - & - & 14 & 10 & 19 & 17 & 15 & 18 & 16 & - \\
\hline $\begin{array}{l}\text { Oral desmopressin } \\
\text { dose }(\mu \mathrm{g} / \text { day) }\end{array}$ & - & - & - & - & 1.2 & 2.4 & 2.4 & 2.4 & 2.4 & 2.4 & 2.4 \\
\hline
\end{tabular}

gene. The ZIC2 transcription factor is one of the most commonly mutated genes in HPE probands (4). The genetic test results of our case showed a deletion in the long arm on the chromosome 13. However as genetic analysis had not been performed for either the child who died with holoprosencephaly or the two miscarriages, nor the parents, we could not comment on the inheritance model of HPE seen in this index case.

Central diabetes insipidus (CDI) is a disease characterized by hypernatremia, hypostenuria and polyuria that develops due to a deficiency of antidiuretic hormone $(A D H)$ secretion from the posterior pituitary. $C D I$ in the neonatal period generally develops as a complication of intrauterine and perinatal diseases (5). Asphyxia, severe infections, intracranial hemorrhage, trauma, hereditary mutations of the gene encoding arginine vasopressin and central nervous system malformations, may be the etiologic factors underlying neonatal CDI. In some rare cases no etiology can be found $(6,7)$. In a study conducted with 12 babies diagnosed with CDI during a ten-year period, it was reported that 10 babies had central nervous system malformations whereas only one patient had semilobar holoprosencephaly and partial corpus callosum agenesis similar to our patient (8). In another study including 23 babies diagnosed with CDI between the ages of 1 day and 9 months, holoprosencephaly was found in 5 babies (9). Other studies reported perinatal asphyxia, intraventricular bleeding and idiopathic cases $(10,13)$. Considering the age at diagnosis of CDI in the literature, it was reported that CDI developed in the early neonatal period in two infants in one study and at the postnatal $90^{\text {th }}$ day in another study $(8,9)$. In another case report, CDI developed on the postnatal $30^{\text {th }}$ day in a baby diagnosed with holoprosencephaly (14). The age of the development of $C D I$ was also in the late neonatal period in some other reports $(11,12)$. In our patient, intracranial hemorrhage, neonatal sepsis and meningitis were excluded, and CDI was accepted as secondary to HPE. Looking at the relationship between CDI and other endocrinopathies, no additional endocrinopathy was reported in some cases $(9,15)$, while anterior pituitary insufficiency accompanied HPE in other cases (8). In our patient, thyroid function tests $\left(\mathrm{TSH}_{1} \mathrm{fT}_{4}\right)$ and blood cortisol levels were normal excluding additional endocrinopathies. A standard treatment for neonatal $C D I$ has not been defined in the literature and the management of these cases is difficult. It has been reported that intranasal desmopressin treatment causes hypernatremia and wide fluctuations in antidiuretic effects due to irregular nasal absorption in babies while oral desmopressin treatment has more positive results 
than the intranasal route $(11,16,17)$. Oral desmopressin treatment was preferred in our patient whose normal sodium levels were achieved with appropriate feeding and fluid support as needed.

In conclusion, although HPE is an uncommon condition, it should be kept in mind that hypernatremic dehydration may develop due to CDI in these patients, even in the early neonatal period. There is no predictive factor for the development of this condition to date, and close follow-up and management should be done accordingly.

Informed Consent: Written consent was obtained from the participants.

Peer Review: Externally peer-reviewed.

Author Contributions: Conception/Design of Study- M.T.A., A.Ç., Z.I.; Data Acquisition- M.T.A.; Data Analysis/InterpretationM.T.A., A.Ç., Z.I.; Drafting Manuscript- M.T.A., A.Ç., Z.I.; Critical Revision of Manuscript- Z.i.,A.Ç.; Approval and AccountabilityM.T.A., A.Ç., Z.i.

Conflict of Interest: Authors declared no conflict of interest.

Financial Disclosure: Authors declared no financial support.

Bilgilendirilmiş Onam: Katılımcılardan bilgilendirilmiş onam alınmıştır.

Hakem Değerlendirmesi: Dış bağımsız.

Yazar Katkıları: Çalışma Konsepti/Tasarım- M.T.A., A.Ç., Z.i..; Veri Toplama- M.T.A.; Veri Analizi/Yorumlama- M.T.A., A.Ç., Z.i; Yazı Taslağı- M.T.A., A.Ç., Z.i.; i İçeriğin Eleştirel İncelemesi- Z.I., A.Ç.; Son Onay ve Sorumluluk- M.T.A., A.Ç., Z.i.

Çıkar Çatışması: Yazarlar çıkar çatışması beyan etmemişlerdir.

Finansal Destek: Yazarlar finansal destek beyan etmemişlerdir.

\section{REFERENCES}

1. Dubourg C, Bendavid C, Pasquier L, Henry C, Odent S, David V. Holoprosencephaly. Orphanet J Rare Dis 2007;2:8. [CrossRef]

2. Makaryus AN, McFarlane SI. Diabetes insipidus: Diagnosis and treatment of a complex disease, review. Clevel Clin J Med 2006;73(1):65-71. [CrossRef]
3. Dubourg C, Kim A, Watrin E, de Tayrac M, Odent S, David $V$, et al. Recent advances in understanding inheritance of holoprosencephaly. Am J Med Genet 2018;178(2):258-69. [CrossRef]

4. Barratt KS, Arkell RM. ZIC2 in Holoprosencephaly. Adv Exp Med Biol 2018;1046:269-99. [CrossRef]

5. Yang YH, Lin JJ, Hsia SH, Wu CT, Wang HS, Hung PC, et al. Central diabetes insipidus in children with acute brain insult. Pediatr Neurol 2011;45(6):377-80. [CrossRef]

6. Ferlin ML, Sales DS, Celini FP, Martinelli Junior CE. Central diabetes insipidus: alert for dehydration in very low birth weight infants during the neonatal period. A case report. Sao Paulo Med J 2015;133(1):60-3. [CrossRef]

7. Qureshi S, Galiveeti S, Bichet DG, Roth J. Diabetes insipidus: celebrating a century of vasopressin therapy. Endocrinology 2014;155(12):4605-21. [CrossRef]

8. Djermane A, Elmaleh M, Simon D, Poidvin A, Carel JC, Léger J. Central diabetes insipidus in infancy with or without hypothalamic adipsic hypernatremia syndrome: Early identification and outcome. J Clin Endocrinol Metab 2016;101(2):635-43. [CrossRef]

9. Kasim N, Bagga B, Diaz-Thomas A. Intracranial pathologies associated with central diabetes insipidus in infants. J Pediatr Endocrinol Metab 2018;31:951-8. [CrossRef]

10. Ueda H, Numoto S, Kakita H, Takeshita S, Muto D, Goto T, et al. Neonatal central diabetes insipidus caused by severe perinatal asphyxia. Pediatr Ther 2016; 6(1): 278. [CrossRef]

11. Atasay B, Berberoğlu M, Günlemez A, Evliyaoğlu O, Adiyaman P, Unal S, et al. Management of central diabetes insipidus with oral desmopressin in a premature neonate. J Pediatr Endocrinol Metab 2004;17(2):227-230. [CrossRef]

12. Yarber B, Wood B. Early diagnosis and treatment of diabetes insipidus in a newborn infant: a case study. Neonatal Netw 1992;11:17-20. pmid:1287448.

13. Quetin F, Garnier H, Brauner R, Vodovar M, Magny JF. [Persistent central diabetes insipidus in a very low birth weight infant] [Article in French]. Arch Pediatr 2007;14(11): 1321-3. [CrossRef]

14. Raisingani M, Gopi RP, Shah B. Use of chlorothiazide in the management of central diabetes insipidus in early infancy. Case Rep Pediatr 2017;2407028. [CrossRef]

15. Molnar Z, Sotiridou E, Dixon H, Ogilvy-Stuart A. Transient diabetes insipidus in a very-low-birthweight preterm infant with intraventricular haemorrhage. Acta Paediatr 2012;101(9):389-90. [CrossRef]

16. Fjellestad-Paulsen A, Paulsen O, d'Agay-Abensour $L$, Lundin S, Czemichow P. Central diabetes insipidus: Oral treatment with dDAVP. Regul Pept 1993;45(1-2):303-7. [CrossRef]

17. Stick SM, Betts PR. Oral desmopressin in neonatal diabetes insipidus. Arch Dis Child 1987;62(11):1177-8. [CrossRef] 